\title{
The Quintessential Features of Iranian Art in Saljuq Period
}

\author{
Ali Piri ${ }^{1} \&$ Mohammad Piri ${ }^{2}$ \\ ${ }^{1}$ Instructor in Department of Art and Architecture, College of Art and Architecture, University of Sistan and \\ Baluchestan, Zahedan, Iran \\ ${ }^{2}$ Assistant in Department of History, College of Literature and Human Science, University of Sistan and \\ Baluchestan, Zahedan, Iran \\ Correspondence: Ali Piri, Instructor in Department of Art and Architecture, College of Art and Architecture, \\ University of Sistan and Baluchestan, Zahedan, Iran.
}

Received: March 27, 2016

Accepted: April 18, 2016

Online Published: May 27, 2016

doi:10.5539/mas.v10n6p219

URL: http://dx.doi.org/10.5539/mas.v10n6p219

\begin{abstract}
The reign of Saljuqian in Iran is considered as a flourishing era of Islamic-Iranian culture. In the Saljuq period, Iran art has experienced and underwent some changes as long as the presence of these evolutions as keystone in Iranian traditional arts have played a significant role in arts such as architecture, painting, pottery and etc. Since the effect of the Saljuq art has been so impressive, even it is not considered as a renaissance period, it can be accounted as one of the significant period in Iranian art. The purpose of this study is to point out some features of the Saljuq art through using descriptive-analytical approach, and to examine some aspects of arts including architecture, pottery, and textile in this period. What is more, the outcomes of the present paper reveal that with regard to the Saljuq architecture, mosques have been formed by nave, dome, and four-porch courtyard derived from Khorasan architecture art. The eminent buildings of this period are Jameh Mosque of Isfahan, Jam Minareh, Sanjar monument in Marv city. Successes have been also achieved in pottery art such as making pottery dishes with over glaze, and under glaze painting and red dishes with white cover. In the field of discovered metal works, there is a variety of bowls, vases and golden, silver and bronze cups which have been carved, embossed and inlayed by picture of animals and plants as well as Kufic script. Moreover, the silk textile known as Ordaki has been one of the brilliant samples of textiles art in this period, decorated with blue Kufic script. In overall, Saljuq arts have paved the way for more development of arts in the subsequent years.
\end{abstract}

Key words: saljuq art, saljuq architecture, saljuq pottery, saljuq textile, saljuq metal works

\section{Introduction}

Always, Iranians have protected the feature of their interest and taste in aristocratic art and seldom used exaggerated and immoderate aspects of art. In Iran, the method of art which has been extracted from large number of people has been infrequent. Although some of merchants and rich people continually have been present to protect artists generously, the art works effected by a famous person' interest and style has been extinct.

In this study, it is attempted to answer all followed questions by library (descriptive-analytical) method:

1) What are the features of Saljuq art?

2) Which one of Saljuq arts and industries has been protected more by dynasty?

3) How was the situation of arts such as architecture, pottery and textile?

One of the features of Saljuq art is that it has been indebted to Sassanid dynasty and continued the achievements of this brilliant age. However, the effects of Sassanid art gradually faded its color and found decorative aspects of significant art under the light of Saljuq artists' innovations. In Saljuq era, the precision and particularity have been considered and exact rules have been legislated for art.

In addition to influence of Sassanid art, the Saljuq art has been affected by foreign art out of Iran borders and Iranians have been profited by other tribes' achievements because of Saljuq territory extent. However, it should not be thought that art of this era has been unoriginal and imitative; but the comparison of existed works show that although Iranian artists have been satisfied by non-native art derivation, the elements of Iranian culture have been mixed with it soon and they have used its native form to convey their purpose and messages. Besides these 
effects and great artists in this era, it has not experienced individuals who could replace their new and special style and change art method. However, Iran art in Saljuq era has enough varieties and special color that has differentiated it from other art methods.

\section{Architecture in Saljuq Era}

The architecture is one of the significant aspects of Iran art that has been blazed especially in making mosques in Islamic era. Although Islam has let its followers to pray in any place when it is time for pray, it has affirmed congregational prayer and appointed them to consider a proper place for performing this religious duty. The first Prophet's action has been making a mosque in Medina. Following this tradition, Muslims have made a mosque for performing ritual duties wherever they have conquered. This fact has made the establishment of first Islamic worship places in Iran. "Tarikhaneh Mosque" in Damghan is one of the first architectural models inspirited from Islamic instructions (Godar, 1998, p. 374). (Figure 1)

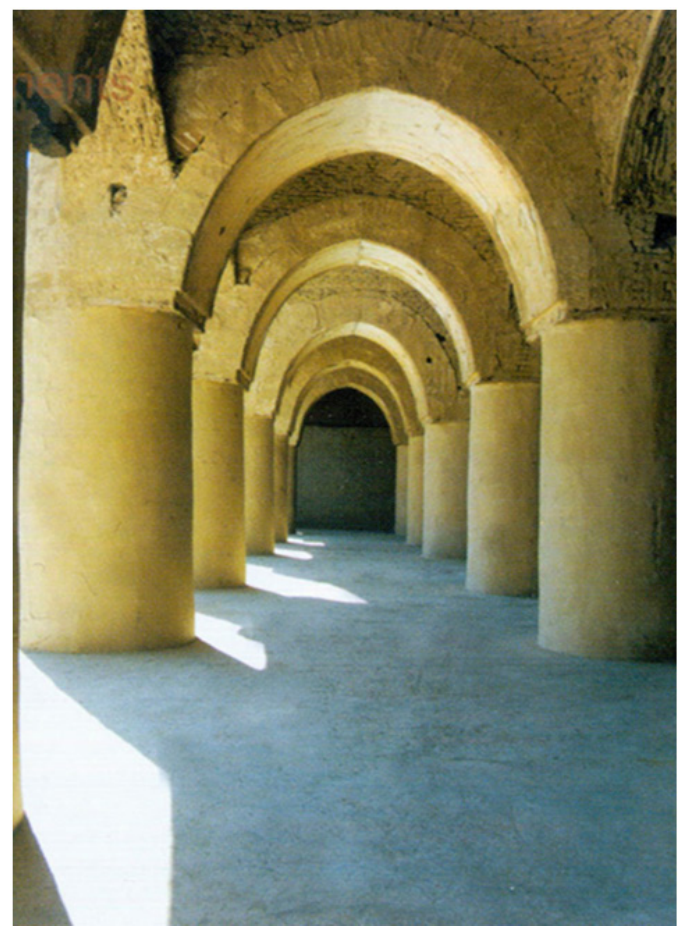

Figure 1. A façade of Tarikhaneh mosque pillars in Damghan, Saljuq era

Source . Damghan Cultural Heritage Organization (http://www.ichto.ir)

During Abbasid Caliphs, there have been attempts for establishing mosques by this method; but this method has not been constant and Iranians have attempted to applied their interest and style in the art of making mosque. Iranian architects have used the features of Sassanid buildings in mosques gradually. They have changed the four-arch which has been a dome on four columns and connected by archers to mosque with little changes. These four-arch ones have been located more in western areas of Iran and their residents have been considered as establishers of four-arch mosques. For these changes, they have changed the direction of the four-arch to southern wall and its fire-place and courtyard to adytum. Therefore, the bases of big mosques have been established in Iran. But in the east of Iran, because of the frequency of building with porch or veranda, the mosque with porch has been established. So, two kinds of mosques with four-arch in the west and with porch in the east have been made in Iran. First, these mosques have been separated from each other and then in Saljuq era, their architectural methods have mixed and mad a kind of Iran big mosques which have been the combination of mosque with yard and four-porch (Godard, 1998, p. 377). The mosques of this era have been the combination of nave, dome and temple with a porch and four-porch courtyard derived from Khorasan architecture (Katly, 1997, p. 11).

Some of art experts believe that before the formation of this kind mosques, Nezamieh school with four-porch has established by Nizam al-Mulk in Saljuq Malik-Shah era in Khorasan and four-porch mosques have been established through inspiration of Nezamieh and then this method has been popular in the west of Iran. These writers have known the method of four porches architecture as the sign of repetition of Iranian art in eras of Iran 
history that the native art has attempted to protect its originality (Grousset, 1957, p. 311).

The most significant four-arch mosques that have been made in Iran including Jameh Mosque in Ardestan, Isfahan, Qazvin, Qom, Natanz, Saveh and also, Jameh Mosque in Brojerd and Golpayegan and Urmia. The Forumad, Zozan, Sabzevar and Nishapur mosques are considered ones with porch (Figure 2).

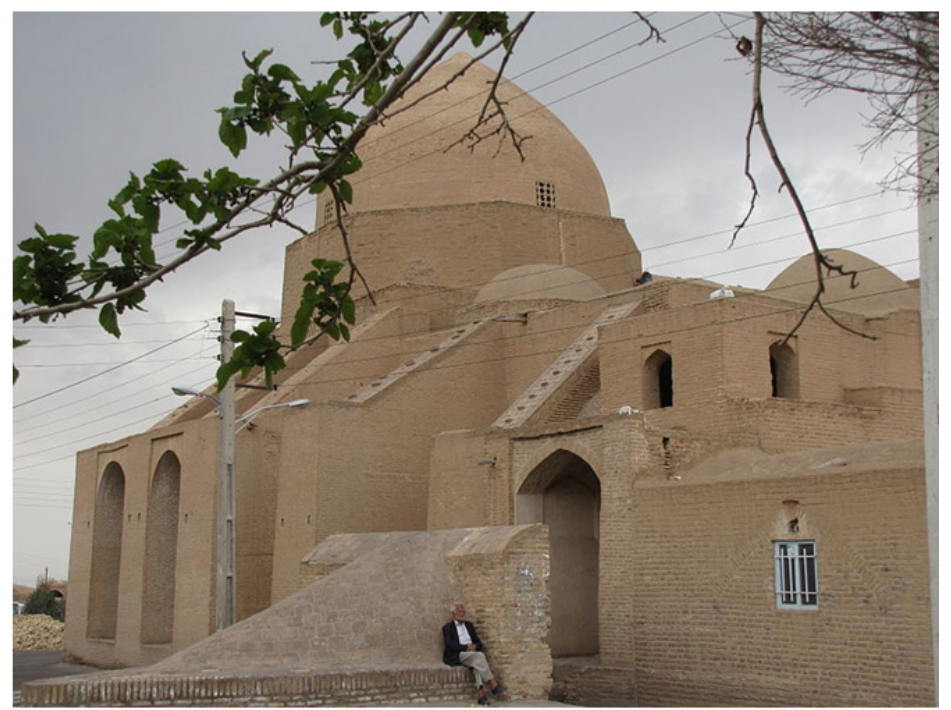

Figure 2. Ardestan Jameh Mosque, the initial building related to Saljuq era

Source . http://commons.wikimedia.org/wiki/File:Jame-Ardestan.JPG

Gradually, this method of architecture has been used in other buildings such as schools and inns and also, it has been used for residential buildings in Khorasan. Iranian architects that have been satisfied with this method, after that they have attempted to decorate mansions and applied to use their interest in beautification of structure. Also, the decorations have been progressed more toward abstracts figures in Islamic era because religiously, each kind of figurative decoration which has been an aspect of idolatry and for this fact, Muslims have been strongly against figurative figures and preceding to abstract figures (Hillen Brand, 2000, p. 35)

Jemeh Mosque in Isfahan is one of the most marvelous structures of Saljuq era. Although this structure has been completed in the next eras, it seems that the architect of this glorious structure has been benchmarked from Kharjerd School by Nizam al-Mulk' direction (Figure 3).

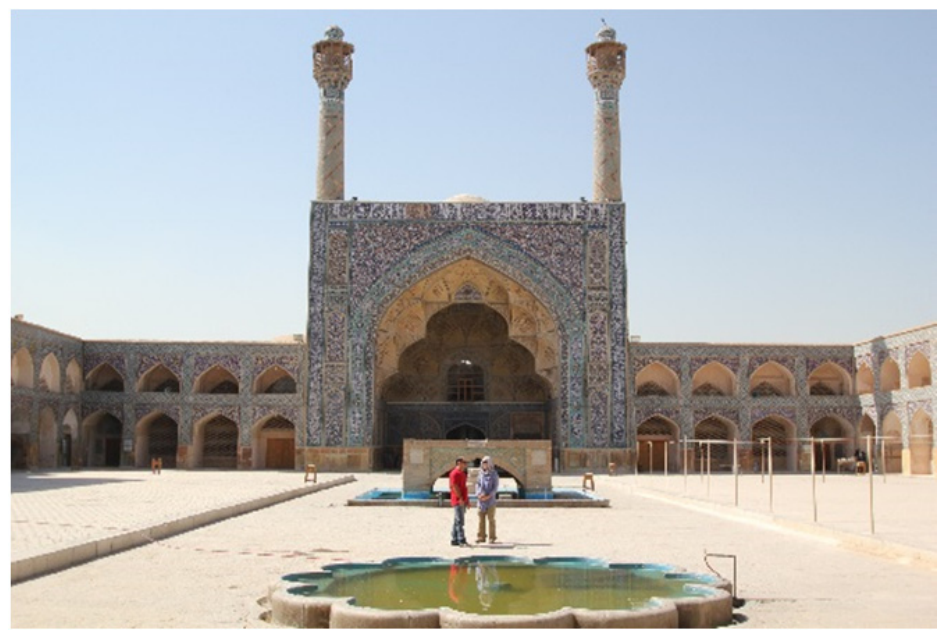

Figure 3. Isfahan Jameh Mosque

Source . http://upload.wikimedia.org/wikipedia/commons/f/fb/Isfahan_Jome_mosque.jpg?uselang=fa

In Isfahan Jameh Mosque, after passing southern porch and reaching to a nave which is located in lower level 
than earth, is one of the most significant examples of Saljuq architecture. There is a big dome which is made of gray-brown bricks. This dome has strength and power in besides its simplicity and its theme has calmness and marvelous beauty. The architect of this building has removed the excrements of dome which is established on quadrangular through using the arches skillfully. This shows the success of Saljuq architects in making dome. They have had significant success based on interior architecture and also calculation and transferring the dome from a square form base to a circle upper the dome and even based on the architecture in figure and dimensions. In theses designs the face of structure is simple sometimes or decorated with geometrical designs and colored tiles. In Qazvin mosque which has been made in 1097, the interior architecture has been applied with one color brick greatly and the sizes have been used based on proportion greatly. This fact has implied the beauty of dome extremely (Rice, 2003, p. 63-64). This feature can be seen in the dome of Jame mosque in Isfahan made in 1073. This structure is not only beautiful but also its decorations are so ingeniously; because the delicate figures special for wood have been used skillfully with bricks in decorations. On the one hand, the architect has roofed the square form room through passing wooden arms from several corners to turn it to an octagon then repeated strutting in corners and put brick arched battens like wooden arms on each other to stable the great dome of mosque finally. In this method which battens are used as frame or framework and holds the structure of dome and rooms on it, has been used the next decades by Gothic World (Rice, 2003, p. 64-65).

Although the method of using bricks in these structures is beautiful and attractive per se, Saljuq architects have not been satisfied with finishing the structure naturally and have attempted to use black and cobalt-blue color to increase its beauties. They have used stucco especially for decorating the adytum greatly. This fact has reached to its climax when the Kufic script has been replaced by Nastaliq script gradually. In this era, the adytum and edges around doors have been decorated by some plaster scripts. In indoor and roofed nave of Jameh mosque in Isfahan, there are some decoration from white plaster, usual brick and gray stones. This plaster decoration has been considered as the base of beautiful tile workings for eras after Saljuq dynasty. The color of tiles has been aqua in that era; but the enamel color has been appeared at the end of Saljuq dynasty in Iran buildings.

Other mosques which reveal Saljuq dynasty are Jameh mosque in Varamin and Zavareh. The Varamin Jameh mosque is made from brick completely and the composition of bricks are different in various parts. Therefore, in addition to this fact that bricks have been used in material of the buildings, they are used in the facade of building and its decoration also. In this building, the arches are cylindrical and keel shaped and porches have a compositing in transferring from square to dome. Half dome and arch or dependent parts to it are considered apparently at least for diversity in the structure of the wall or constitute the transferring phase from one form to another. Totally, beautification in whole building is subordinated to architecture designs. Like what has been used in passing from the square to octagon and from the wall to arch.

In Varamin Jameh mosque (Figure 4), different methods of beautification such as different sights of imagery in stucco, minarets and enamel colors have been used. There are also plants figures; but its popular figure is geometrical or with inscription. Inscriptions include religious or historical contents and have been used for recognizing the purpose, the circumstance of building and the history of its establishing. Geometrical designs have been used for consistency in main lines of the building (Boyle, 1992, p. 592).

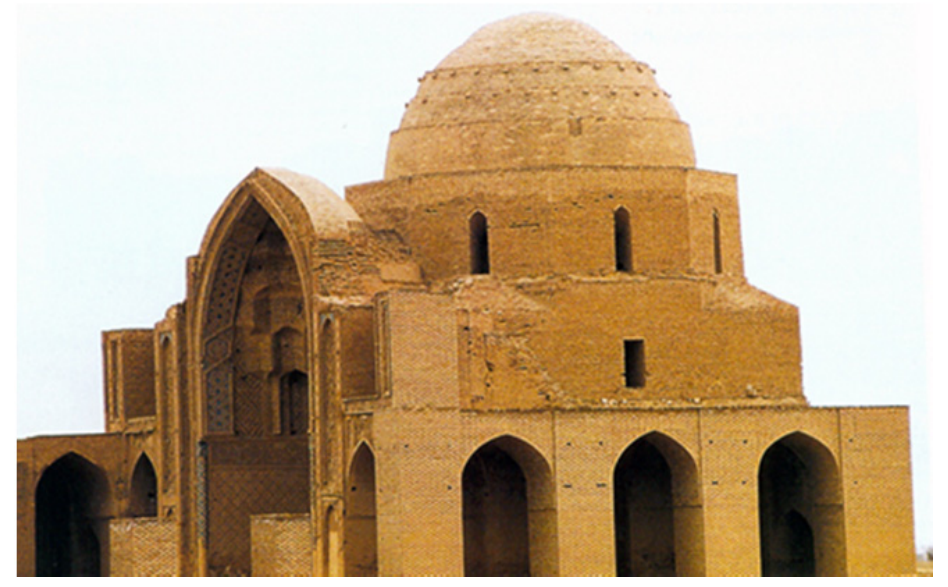

Figure 4. Varamin Jameh Mosque

Source . http://upload.wikimedia.org/wikipedia/commons/f/f4/Varamin_masjed.jpg?uselang=fa

The domes of some mosques have been made separately and as usual the around structures have been established 
later that the domes; but in Zavareh mosque, whole building has been made together. In Saljuq era, the significant successes have been achieved in making double dome. The innovations in this era have been a preface for future art in Iran architecture especially in Timurid Empire (Katly, 1997, p.13). In Saljuq era, for completing the structure of four-porch mosques, a new kind of minaret has been propagated in the form of a long and thin cylinder with square form base. These minarets have been made at the beginning of the $5^{\text {th }}$ century (hijri) and their bases have been octagon or star form. This kind of minarets have been propagated completely in $8^{\text {th }}$ century (hijri) and for more attraction and beautification, the brick decorations with geometrical figures have been used for them (Katly, 1997, p. 14).

The third kind of Saljuq mosques is the one with roofed corridor with a cylinder and a dome at the center. Two of these kind mosques have been found yet which are in Mohammadiyeh near Nain (Godard, 1998, p. 411).

Schools are another kind of Saljuq buildings which have had connection with religious and spiritual life of Islamic society. Schools of this era have been made basically for education of religious deed, reciting or reading the holy Quran and its interpretation in eastern regions specially Khorasan. Iran old schools have been as a simple house which have been allocated to classes and made by teachers near their houses or mosques. Therefore, from the middle of $5^{\text {th }}$ century (hijri) schools have lost their poor and simple situation and developed considerably. The major reason of this fact has been the weakness of Saljuq's increasing caliphate and power. Through Saljuq dynasty, religious science schools have been changed from private to state ones and governed by the government. The first example of these schools has been made in 1064 by Nizam-al-Mulk, Alp Arsalan and Malik-Shah's minister in Baghdad. Gradually, these kind schools have been made in Nishapour, Isfahan, Herat, Balkh, Khar Gerd, Tous, Basra and Mousal. Nizam-al-Mulk's successors have followed him and developed schools throughout Saljuq dynasty. "Khar Gerd Nezamieh" has been a military school which has had services parts around the yard and chambers for religious student's residence (Katly, 1997, p.16).

In addition to religious buildings, the architecture of unreligious buildings has been grown and developed. The ruin of a bridge, a bathroom in Negar and various inns in the area of Saljuq dynasty are still stable. The inns like mosques have a courtyard (bigger) with a four-porch. They have been roofed in cold regions. The structure and general form of inns include a central yard with four porches which has been surrounded by room or corridor and this composition has been made in one or two floors. Sometimes, they have made a dome for presenting entrance and a porch to show its pathway (Godard, 1998, p. 418).

Another aspect of Saljuq architecture is interior decorations of buildings. Usually, different buildings have been decorated with plaster work in this era. The subjects of these plaster works are natural scenes, king and princess, emirs, musicians, maids and courtiers. In addition to plaster work, Saljuq architects have decorated buildings with brick and tiles (Dimand, 1986, p.97). Using tiles and the development of architectural decorations are the innovations of Saljuq era. This method has been form for the first time in 1088. Soon, the tile working has been used in architectural decoration. First, this fact has been used in the minaret of Damghan Jameh mosque in 1106, in Seen Mosque near Isfahan in 1131, in the inscription of "Monarsaraban" of Isfahan and after that in the north, Azerbaijan and Maragheh. The art of tile working has found its position in Maragheh and even the outside decoration of building has been started there by Gonbade-e-Sorkh.

\section{The Pottery Art in Saljuq Era}

In addition to making buildings, Saljuq dynasty has been the great patron of delicate arts. The diversity and quality of dishes and potteries of this era show the mass of their productions greatly. In Saljuq era, several potteries have been created. The first dishes are the ones which are without any stylus or its stylus has a subsidiary figures and the main decoration has been on green and yellow glazes. These dishes like Mesopotamia dishes are complete imitation from imported potteries made by China. However, this composition has a short life because gradually have disappeared in $8^{\text {th }}$ and $9^{\text {th }}$ centuries (hijri). The second group has been presented by dishes with red body and there is a white cover on them. The delicate design has had a stylus of a white cover and also a stylus under a slate gray glaze. In this era, there have been similar designs on metals which have had more the figure of birds. The third groups are the potteries that a great part of their color is removed to make a complementary design. These deigns are under a dark green glaze. Making heavy bowls with a large leg and bandy edge, long drinking cups like the neck of birds with designs of birds on them have been popular. Generally, it can be said in this era, the dishes with great and glorious designs and the dishes with delicate and billowy designs have been made with technique and versatile designs (Rice, 2003, p. 68). The bowls have been made with beautiful white body and blue and green decorations. On these dishes, the decorations have been molded and being stylus and sometimes toreutic has been applies and they have had the quality similar china. On other dishes, the cream color has been replaced by dark blue or brown glazes and this method has been used skillfully 
for the beautification of big dishes. It is also used in small coffee-cups. Some of molded dished which have been famous as "Lak Abi" have been with embossed blue, yellow, purple, green and pink parts. The center of making these dishes has been Kashan. A kind of dish with silhouette designs on the beautiful white body under a great white glaze or an aqua color with black glaze has been made in Ray.

Totally, the potteries of Saljuq era have been reached to their climax and priority from 1236 to 1286 in making two group valuable dishes means glossed ones and what has been called vitreous enamel or colored-figured dishes. The techniques of making these two groups have been difficult and complicated. The body of vitreous enamel dishes has been white, soft and consistent and with light blue, green or purple. First there is a design under the glaze and then dishes are put in to the furnace. After that, black lines around figures and details of designs with crystal-glass color with many diverse colors such as blue, gray, aqua, green, yellow, brown, black, red and gold are added to it. Sometimes, the backgrounds have been colored. This fact has given more diversity to designs. In addition to white, the light purple or aqua colors have been popular. Then, they have fixed the colors by putting the dish for second time in furnace and this method has created the potteries with bright and fixed colors.

The most popular centers for pottery have been Rey, Kashan, Nishapour, Arak and Saveh. In this era, there have been made golden potteries decorated with human sculpture. Different figures and techniques have been used in Saljuq potteries. Bowls, jugs and vases have been decorated with gilt and different colors and figures have been embossed (Grousset, 1957, p. 309)

\section{The Textile in Saljuq Era}

The textile industry in Saljuq era has the different aspects of past art like other arts. But the old designs have been replaced gradually with designs which there are the combination of scroll lines with date leaves form. Saljuq weavers have not been interested in bright colors of textiles but they have understood the simple contrast of light and dark colors. These weavers have usually used two colors sky blue or dark blue and black or green on the white or red background. They have applied the simple designs at the beginning of Saljuq era. But weavers have been skillful in applying diverse designs gradually at the end of $7^{\text {th }}$ and $8^{\text {th }}$ century (hijri) and succeed to weave the most complicated and delicate designs. The every other and two-ply chess design have been popular and the design of these textiles have been repeated from industrial and familial signs or old traditions of this art such as double-headed eagles, peacock, lion and winged lion with eagle head that at circular units of edge the design of citron or octagon have been repeated. The poetical scenes and natural landscapes have been copied probably from the designs of their contemporary dishes. The silk textile called "Ordaki textile" which is one of the great examples of textile in this era. The blue Kufic scripts have been surrounded by yellow elliptical flowers on blue and the gaps have been covered by thin blue and yellow leaves and limbs (Arberry, 1967, p. 23).

Saljuq governors have been great supporters of delicate texture and less width and length textiles especially with line designs covered whole textile. These textures have been accepted by people (Rice, 2002: 83).

\section{Saljuq Metalwork}

The metalwork has been another art in Saljuq era that has developed. In this era, bronze, gold and silver dishes have been produced with decorative designs (Price, 1977, p.65). The achieved Saljuq goods that most of them have been found in Central Asia and Caucasus are protected in Russia museums and collections. These goods include bowels, vases and different kinds of cups that figures of animals, plants and also Kufic scripts have been designed on scroll background. The decorative designs of these dishes have been carved, sometimes embossed and inlayed. There is a bowel in Berlin museum that there is a figure of a citron which a musician is carved inside of it (Arberry, 1967, p. 137-138).

The most important success of Saljuq metalworkers has been red copper and white silver inlaying on the bronze dishes and then brass ones. One sample of this art in Saljuq era is a ewer in Hermitage museum that a beautiful peacock sits on a tree and the marquetry of metal circles and squares are shown on it. In this museum, there is a brass pen-case which is inlayed with copper and silver with the figures of faces, little birds, leaves and limbs on it. Apparently, this pen-case has been one of the oldest samples of metal inlayed works which is found yet and referred to 1148 in Khorasan. But the most important metal and inlayed works in Saljuq era is a pot or bucket which is in Hermitage museum. This dish has been molded by Mohammad ibn Vahid and its toreutic by Masoud ibn Ahmad for a merchant in Zanjan. The figures of this valuable dish which has been made from silver and copper has five lines that two of them are the banquet scene of crown and hunting and others are decorated by Kufic scripts and Arabic scripts. The vertical part of Arabic script is changed to humans' body and head which have been designed beautifully and precisely (Katly, 1997, p. 390). 
A ewer full of figures has been made in Herat in 1181 which is in Tbilisi Museum now. The body of the ewer is ridge and there is a figure of astrological signs on its top. This figure has been popular in Khorasan and it is seen around Khorasan copied of china dishes. Like this kind of ewer, some ewers and sprinklers have been in Britannia museum which are brass. On the bowel and cylinder of these dishes, there are the figures of birds and lions. Their head are changed to a human figure which is covered by flowers and wrapped bushes. Other works of this metalwork school include a pen case, inkstand, big candlesticks with separate birds on the body and embossed lions on the frame of the dish and then the ewers and teapots in the form of a pear like a lamp and their handles are like lions which are drinking water. The school of carving and inlaying metals has protected their technical quality and values up to the Mogul attack (Arberry, 1967, p. 211).

The gilt work has had a considerable position in Saljuq era. Most of Saljuq jewelries have been earrings and necklaces which some of them are made in animals and birds forms. There are three kinds of these metals in Metropolitan museum in New York: a lunate earring like a bird which is separated by date tree figures. This earring is like a necklace in Berlin museum based on its method of making. These two pieces are related to $5^{\text {th }}$ century (hijri). An earring like a bird and a necklace like a lion are found from $12^{\text {th }}$ and $13^{\text {th }}$ century (hijri) which the decoration of head and skin of the lion are made by twist gold string and in the hole of its eyes the precious stones are used (Dimand, 1986, p. 138).

Another brilliant art of Saljuq era is vitreous enamel. Beautiful samples of vitreous enamel are in different museums. The greatest work is a bronze plate in Innsbruck museum. This plate is decorated with several colors with humans, birds and animals figures. These figures are inside a bergamot that is divided from the figures of date trees and dancers. Totally, the style of Saljuq metalworking has been soft, juicy, explicit and tendentious to details (Katly, 1997, p. 40).

\section{Conclusion}

Saljuq art is the connection between the traditions of Iranian ancient arts and aspects of Islamic art. In this era, diversities have happened in the field of art which changed to infrastructure for future generations. The great aspect of Saljuq art can be seen in architecture, pottery, textiles and metalwork. In architecture, the method of making fire temple has been used in designing mosques, schools, inns and other buildings and through inspiration from four-porch design they have become the original symbols of architecture. In this era, the plaster and brick have been used not only for the substance of the buildings but also for beauty and Saljuq architects have used skillfully tiles for the decoration of building façade for the first time. Also, the Saljuq pottery has had high quality and diversity and potters have used developed skills. Production of colorful and glossy potteries which have been put in furnace twice, have been popular from that time. In relation to textiles, in addition to their simplicity of designs, there are innovations in the method of texture and gradually there have been a background for examining next century weavers' taste by using the figures of animals and nature. The art of metalworking have been increased in Saljuq era in toreutics, inlaying, marquetry and using gold, silver and copper for embossing on metals have been developed greatly. The valuable sample of jewelries and different metal dishes have been founded which are decorated with precious stones. The vitreous enamel is the other art of Saljuq era that nowadays is adorable in world museums. Totally, the Saljuq era can be considered as one of the golden eras of Islamic-Iranian art which has been the infrastructure of art growth for next era.

\section{References}

Arberry et al. (1967). Iran Heritage. (Ahmad Birashk et al.). Tehran: Translation and Publication Institution.

Boyle, G. A. (1992). Iran History from Saljuq to Ilkhanate Collapse. (Hassan Anousheh). (2nd Ed.). Tehran: Amirkabir.

Dimand, S. M. (1986). Guidance to Islamic Industry. (Abdullah Faryad). (2nd Ed.). Tehran: Scientific and Cultural Publication.

Godard, A. (1998). Iran Art. (Behrouz Habibi). (2nd Ed.). Tehran: Shahid Beheshti University Publication.

Grousset, Rene, et al., (1957). Iran Civilization. (Javad Mohebi). Tehran: Gothenburg.

Hillen, B., \& Robert, (2000). Islamic Architecture: Form, Function and Meaning. (Iraj Etesam). Tehran Urban Process and Planning Company.

Katly, Margarine, et al. (1997). Saljuq and Khwarizmi Art. (Yaghoub Ajand). Tehran: Mowla.

Price \& Christian (1977). Islamic Art History. (Masoud Rajabniya). Tehran: Translation and Publication Institution.

Rice, T. D. (2003). Islamic Art. (Mah Malek Bahar). (2nd Ed.). Tehran: Scientific and Cultural Publication. 


\section{Copyrights}

Copyright for this article is retained by the author(s), with first publication rights granted to the journal.

This is an open-access article distributed under the terms and conditions of the Creative Commons Attribution license (http://creativecommons.org/licenses/by/3.0/). 